University of Michigan Law School

University of Michigan Law School Scholarship Repository

1969

\title{
Judicial Valour and the Warren Court's Labor Decisions
}

Theodore J. St. Antoine

University of Michigan Law School

Available at: https://repository.law.umich.edu/book_chapters/198

Follow this and additional works at: https://repository.law.umich.edu/book_chapters

Part of the Labor and Employment Law Commons, and the Supreme Court of the United States

Commons

\section{Publication Information \& Recommended Citation}

St. Antoine, Theodore J. "Judicial Valour and the Warren Court's Labor Decisions." In The Warren Court: A Critical Analysis, edited by R. H. Sayler et al. New York: Chelsea House, 1969.

This Book Chapter is brought to you for free and open access by the Faculty Scholarship at University of Michigan Law School Scholarship Repository. It has been accepted for inclusion in Book Chapters by an authorized administrator of University of Michigan Law School Scholarship Repository. For more information, please contact mlaw.repository@umich.edu. 


\title{
THE WARREN COURT A Critical Analysis
}

\author{
Editors \\ Richard H.Sayler \\ Barry B.Boyer \\ Robert E.Gooding,Jr.
}

\section{Chelsea House NewYork}




\title{
JUDICIAL VALOUR AND THE WARREN COURT'S LABOR DECISIONS
}

\author{
Theodore J. St. Antoine*
}

T AWYERs who practice regularly before the Supreme Court are Likely to prepare their arguments with a specific Justice in mind. The choice does not necessarily turn on who might be the swing vote in a given case. Often it is just a matter of which Justice can be relied upon, because of his particular interests and his insight, to search out the strengths and weaknesses of the opposing positions, and to see that all the hard questions are asked. In a labor case during the early years of the Warren Court, that would usually have meant Justice Frankfurter. Later on, depending on the circumstances, it might have been Justice Harlan or Brennan or Fortas. It has probably never been the Chief Justice.

Yet now as I look back upon the whole sweep of the Warren Court's labor decisions over the past decade and a half, I am struck by the sudden suspicion that many members of the Supreme Court's labor bar ${ }^{1}$ may have outsmarted themselves. They were, perhaps, like the fabled fox who knew many things; they failed to recognize that it was the Chief Justice who knew the One Big Thing. For the major contribution of the Warren Court to the development of labor law has not depended on the kind of subtle statutory interpretation that is needed to wend one's way through the labyrinthine secondary boycott passages of the Taft-Hartley Act. Instead, the Court's main achievement in the labor field involved a simple but fundamental restructuring of intergovernmental relations. What the Court did, in a series of decisions that were hotly controverted at the time but have quietly won general acceptance since, was to nationalize the regulation of labor relations in industries affecting interstate commerce. The Court's action reflected the same characteristically audacious Warren approach toward established state institutions which was displayed in dealing with reapportionment and civil rights.

The importance in the Court's eyes of "federal pre-emption"the exclusion of state substantive law from areas regulated by Congress-can be shown to an extent simply in quantitative terms. Some-

- Associate Professor of Law, University of Michigan. A.B. 1951, Fordham College; J.D. 1954, University of Michigan.-Ed.

1. In fairness I should mention that I was a junior member of this group (as union counsel) for about half the span of the Warren Court. No one could be more guilty than I of the accusation in the text. 
what arbitrarily, I have labelled about 110 labor decisions of the Warren era as "important." Of these, almost forty-or over a third -deal either directly with the metes and bounds of the pre-emption doctrine, or with issues which would not have arisen but for the displacement of state law by federal. ${ }^{2}$ I shall discuss the cases in two categories: those decisions concerned with the extent to which state law may still operate in areas subject to federal regulation; and those decisions concerned with the development of federal law to replace state law as the basis for enforcing collective bargaining agreements. Thereafter, I shall add a few words about some of the other significant labor decisions of the Warren Court.

At the time Chief Justice Warren assumed office, the pre-emption doctrine in its application to labor relations was still in its adolescence. The well-nigh axiomatic principle had been established that a state could not directly impede the exercise of federal rights of self-organization, for example, by imposing onerous licensing requirements on union agents. ${ }^{3}$ But states were still free to regulate such labor activities as "quickie" strikes, which technically were neither protected nor prohibited under federal law." More important, no clear rationale had been evolved to justify conclusions that particular kinds of conduct fell either within or without the ambit of state regulation. And there had been little airing of the underlying policy considerations which go to the very heart of our federal system: the balancing of the need for a uniform national policy in matters affecting the country as a whole against the need to accommodate regional differences and desires for local experimentation.

The first term of the Warren Court ushered in the vanguard elements of today's pre-emption theory. In Garner v. Teamsters $U^{\text {Union }}{ }^{5}$ the Court held that a state injunction could not duplicate a federal remedy by forbidding conduct proscribed under the National Labor Relations Act. Diversity of procedures was said to be as apt to produce conflicting adjudications as diversity of substantive rules. It soon became apparent, however, that a majority of the Court regarded a deficiency in the federal remedy as a sufficient reason for sustaining state jurisdiction. Thus, employees or employers suffering monetary losses through tortious conduct that was also an unfair

2. Chief Justice Warren himself authored eleven opinions in the approximately 110 cases I surveyed; five dealt with pre-emption. His opinions included four dissents, three on this subject. The Chief Justice has consistently been one of the most propre-emption members of the Court.

3. Hill v. Florida, 325 U.S. 538 (1945).

4. UAW-AFL v. WERB [Briggs \& Stratton Corp.], 336 U.S. 245 (1949). For a more recent approach, see Teamsters Local 20 v. Morton, 377 U.S. 252 (1964).

5. 346 U.S. 485 (1953). 
labor practice could maintain a state court action for damages, since the National Labor Relations Board had no general power to award full compensatory relief. ${ }^{\circ}$ At this juncture Chief Justice Warren stepped in to protest a state's awarding damages, especially punitive damages, for conduct regulated by the federal labor statutes. As he saw it, the uniformity of regulation by which Congress sought to secure nationwide industrial peace would be undermined by the numerous variations in state laws and the "provincialism" of local juries. ${ }^{7}$

The Warren views did not entirely prevail, but their influence was plainly felt in San Diego Building Trades Council v. Garmon, ${ }^{8}$ which remains the Court's most definitive statement on pre-emption. There the Court in handling the pre-emption issue shifted from an emphasis on the nature of the state relief sought (was it more adequate than the federal remedy?) to an emphasis on the nature of the activity in question (was it regulated under federal law?). The now-famous test was enunciated that if conduct is "arguably" protected by section 7 of the NLRA, or "arguably" prohibited by section 8, exclusive primary jurisdiction rests in the NLRB and state (or federal) courts are precluded from acting. Earlier decisions which had appeared to rely on the deficiency of the federal remedy were explained as upholding state court jurisdiction because violence or threatened violence was present, or because the activity was of "merely peripheral concern" to the federal statutory scheme. ${ }^{\circ}$

The soundness of all this surely is not self-evident. Under the expansive pre-emption doctrine, states have been sharply limited in the role they can play as "laboratories" for social experiment. Numerous restrictions have been imposed on customary state functions. Thus, although the states can still assert their police power to maintain public order, they cannot take over a public utility to halt a strike. ${ }^{10}$ Laws not dealing specifically with labor relations, such as state antitrust statutes ${ }^{11}$ and even traditional common-law libel doctrines, ${ }^{12}$ may also run afoul of the pre-emption principle. This is so

6. United Constr. Workers v. Laburnum Constr. Corp., 347 U.S. 656 (1954); UAW v. Russell, 356 U.S. 634 (1958).

7. UAW v. Russell, 356 U.S. 634, 650-51 (1958) (dissenting opinion).

8. 359 U.S. 236 (1959).

9. 359 U.S. at $241-43$, citing United Constr. Workers v. Laburnum Constr. Corp., 347 U.S. 656 (1954) (threatened violence); UAW v. Russell, 356 U.S. 634 (1958) (mass picketing); IAM v. Gonzales, 356 U.S. 617 (1958) (wrongful expulsion of member from union).

10. Street, Elec. Ry. \& Motor Coach Employees Div. 1287 v. Missouri, 374 U.S. 74 (1963).

11. Teamsters Local 24 v. Oliver, 358 U.S. 283 (1959).

12. Cf. Linn v. Plant Guard Workers Local 114, 383 U.S. 53 (1966) (libel action 
even though it is by no means clear that Congress is as eager as the Supreme Court would suggest to ensure the unsullied uniformity of federal regulation. ${ }^{13}$ In extending the pre-emption doctrine, the Court nonetheless moved boldly ahead, willing to risk local losses to achieve national gains, and willing too, it would seem, to risk congressional displeasure for reading more into the statute than the legislature may have intended.

On balance, I think the Court has acted wisely. Labor law continues to be one of our most divisive domestic issues, and much of the divisiveness runs along regional lines. Federally enforced uniformity thus seems peculiarly necessary, lest either unions or employers be unduly favored in particular states. Such regional variations could hardly fail to have an adverse impact on the nation's economy. For example, plants might be lured from place to place while labor bitterness constantly deepened. The present healthy trend toward a leveling of wage rates for similar jobs across the country could well be reversed. Of course, a different result in almost any given Supreme Court pre-emption decision would doubtless not have had dire consequences. But by now we probably have sufficient experience under the Court's broad pre-emption doctrine to conclude that vital local interests have in fact suffered no serious injury. This alone may be enough to indicate that the Court was right when it began to tip the scales, as a matter of general policy, in favor of national interests rather than local concerns.

The Warren Court's vigor in furthering the primacy of federal law was demonstrated even more strikingly in its rulings on the enforcement of collective bargaining agreements. Labor contracts were traditionally enforced in accordance with state substantive law. It was often hard to sue a union in the state courts, however, because of the difficulty of obtaining jurisdiction over an unincorporated association. Therefore, in 1947, Congress wrote section 301 into the Taft-Hartley Act ${ }^{14}$ to provide that suits on contracts between unions and employers could be brought in the federal district courts. Unions were explicitly made competent to sue or be sued as entities.

But what was the substantive law to be applied in 301 suitsfederal or state? If section 301 were to be treated as merely procedural, with state substantive law applicable, the provision would

maintainable only if defamation in course of labor dispute is malicious and actually injurious).

13. When Congress enacted the Landrum-Griffin Act in 1959 to provide the first comprehensive federal regulation of internal union affairs, it specifically negated any general intent to exclude concurrent state regulation. See 29 U.S.C. $\$ 523$ (1964).

14. 29 U.S.C. 8185 (1964). 
be of dubious constitutionality; article III of the Constitution confines the jurisdiction of the federal district courts to cases involving diversity of citizenship or a federal question. Yet section 301 was silent on the question of applicable law, and Congress had furnished no clear guidance.

After one earlier inconclusive skirmish, ${ }^{15}$ the Supreme Court came to grips with the problem in Textile Workers Union v. Lincoln Mills. ${ }^{16}$ A union sued an employer in federal court for specific performance of the arbitration provisions in the parties' collective contract. Jurisdiction was contested. Justice Douglas, for the Court, cut the constitutional knot with one swift stroke, declaring that "the substantive law to apply in suits under $\S 301$ (a) is federal law which the courts must fashion from the policy of our national labor laws."17 Once this was established, jurisdiction could constitutionally be reposed in the federal judiciary.

Perhaps the magnitude of the Court's undertaking in Lincoln Mills can best be gauged by attending to the highly literate criticism leveled at the decision in a classic article by Professors Alexander Bickel and Harry Wellington of the Yale Law School. ${ }^{18}$ The authors point out, quite correctly, that Justice Douglas' previously quoted conclusion, "which intrudes upon state power, which finds no support in the language of the statute and insignificant support in the legislative history, received no explanation in the opinion."19 But their ultimate objection to Lincoln Mills is far more profound. With an almost mystical concern for the institutional integrity of the judiciary, Bickel and Wellington argue that section 301, as read by the Supreme Court, demands of the federal courts a task to which they are "enormously unequal," and "its imposition on them is therefore capable of damaging their usefulness for the essential duties that they are suited to perform." 20 The authors concluded that when Congress confers responsibilities upon the federal courts which are beyond their institutional capabilities, the proper disposition is a "remand" of the matter to Congress for further consideration. Remand is to be achieved through "any form of dismissal for lack of jurisdiction which does no violence to the statutory language."21

\footnotetext{
15. Association of Westinghouse Salaried Employees v. Westinghouse Elec. Corp., 348 U.S. 437 (1955).

16. 353 U.S. 448 (1957).

17. 353 U.S. at 456. Justice Frankfurter dissented in a massively documented eightysix-page opinion in which he sought to show that $\$ 301$ did not create substantive rights but was only procedural. 353 U.S. at $\mathbf{4 6 0}$.

18. Legislative Purpose and the Judicial Process: The Lincoln Mills Case, 71 Harv.

L. REv. 1 (1957).

19. Id. at 35-36.

20. Id. at 22-23.

21. Id. at 35 .
} 
The task shouldered by the Supreme Court, despite the grave apprehensions of Bickel and Wellington, was the task of fashioning a body of federal contract law to govern the enforcement of collective agreements. Its sources were to be the policies of the federal labor statutes, state contract law where appropriate, arbitrators' decisions, and so on. Bickel and Wellington looked at these "bits and pieces" and were aghast; the Court had faith that "judicial inventiveness" would find a way. ${ }^{22}$ Perhaps that is the difference between professors and practical men. By hindsight, at any rate, it is hard to find justification for the fears of the two perceptive Yale critics.

Possibly an explanation for the easy survival of the federal judiciary lies in the next maneuver executed by the Warren Court. Having boldly staked out a claim in Lincoln Mills to the whole of the labor contract domain, the Court then turned around in the Warrior trilogy ${ }^{23}$ and delegated to arbitrators the principal responsibility for interpreting and applying collective bargaining agreements. Courts are to order arbitration of grievances under a contract "unless it may be said with positive assurance that the arbitration clause is not susceptible of an interpretation that covers the asserted dispute."24 Moreover, an arbitrator's award is to be enforced by a court without a review on the merits, so long as the award is not the product of fraud or capriciousness. Thus, through the Warrior approach, the Court may have finessed many of the problems envisaged by Bickel and Wellington.

Even so, the Warren Court has managed to build up a fairly substantial body of basic contract doctrine. For instance, a labor agreement may be binding on a successor employer even though he has not signed it. ${ }^{25}$ Available grievance and arbitration machinery has to be exhausted before there can be resort to a court suit on a contract. ${ }^{26}$ And in the absence of a federal statute of limitations, state statutes apply to section 301 actions. ${ }^{27}$ These are the kinds of questions one might have anticipated the Court would have to resolve. They hardly seem a threat to its institutional capacities.

Perhaps the most nettlesome current issue of labor contract enforcement is the impact of the Norris-La Guardia Act. Here, more than anywhere else, the Supreme Court may be open to the charge

22. Textile Workers Union v. Lincoln Mills, 353 U.S. 448, 457 (1957).

23. United Steelworkers v. American Mfg. Co., 363 U.S. 564 (1960); United Steelworkers v. Warrior \& Gulf Nav. Co., 363 U.S. 574 (1960); United Steelworkers v. Enterprise Wheel \& Car Corp., 363 U.S. 593 (1960).

24. United Steelworkers v. Warrior \& Gulf Nav. Co., 363 U.S. 574, 582-83 (1960).

25. John Wiley \& Sons, Inc. v. Livingston, 376 U.S. 543 (1964).

26. Drake Bakeries, Inc. v. Bakery Workers, Local 50, 370 U.S. 254 (1962); Republic Steel Corp. v. Maddox, 379 U.S. 650 (1965).

27. UAW v. Hoosier Cardinal Corp., 383 U.S. 696 (1966). 
that it failed to think through the implications of applying federal substantive law to suits brought under section 301 . So far, the Court has held that the Norris-La Guardia injunction ban does not prevent specific enforcement of an agreement to arbitrate, ${ }^{28}$ but that it does prevent an injunction by a federal court against a strike in breach of contract. ${ }^{29}$ Two embarrassing questions are left. Does Norris-La Guardia prevent a decree ordering specific performance of an arbitrator's award directing a union to halt a strike? And, does Norris-La Guardia apply to prevent a state court injunction against a strike in breach of contract?30 If the last question is answered "yes," that will be an ironic denouement to the Taft-Hartley Congress' efforts to increase the range of employer remedies against unions. If the question is answered "no," the anomaly may be that state courts will become, by employer choice, the principal formulators of federal law in this important area. ${ }^{31}$ These logical difficulties could have been avoided if the Supreme Court had applied state substantive law in Lincoln Mills. The chances are, however, the Court would have come out the same way even if it had foreseen these problems. For the policy tug of having uniform federal law govern contract enforcement would have remained. And in a conflict between logic and policy, the Warren Court has never been prone to favor logic.

Several other labor doctrines of the Warren Court mirror the libertarian philosophy that has permeated the Chief Justice's tenure. At least two should be mentioned-free speech and individual rights.

After being in eclipse for almost a decade, ${ }^{32}$ the concept of peaceful picketing as a form of free speech protected by the first amendment enjoyed a resurgence in the late years of the Warren Court. In one case the Court engaged in some rather strained statutory interpretation to reach the conclusion that the 1959 amendments to the Taft-Hartley Act do not forbid consumer picketing aimed at a particular nonunion product being distributed by a neutral retailer; ${ }^{88}$ otherwise, difficult constitutional questions might have been raised. In another case the Court held that a state court injunction

28. Textile Workers Union v. Lincoln Mills, 353 U.S. 448 (1957).

29. Sinclair Ref. Co. v. Atkinson, 370 U.S. 195 (1962).

30. State courts retain jurisdiction to enforce collective agreements, but they must apply federal substantive law under 301. Teamsters Local 174, v. Lucas Flour Co., 369 U.S. 95 (1962).

31. Union removal of $\$ \mathbf{s 0 1}$ suits from state to federal court may solve this dilemma. See Avco Corp. v. Machinists Aero Lodge 735, 390 U.S. 557 (1968).

32. See, e.g., Teamsters Local 695 v. Vogt, Inc., 354 U.S. 284 (1957).

33. NLRB v. Fruit \& Vegetable Packers \& Warehousemen Local 760 [Tree Fruits], 377 U.S. 58 (1964). 
against the peaceful picketing of a business in a privately owned shopping center violated the first amendment. ${ }^{34}$ The Court went on to say that ordinarily picketing can be forbidden only when it has an illegal end, and rejected the notion that the nonspeech aspects of picketing render the first amendment completely inapplicable. The Court also rewrote the legislative history of the union security provisions of the Railway Labor Act for the purpose of avoiding first amendment issues. In two different cases the Court held that the Act prevented railroad unions from using dues money collected from employees under a union shop agreement for political purposes, if the employees objected. ${ }^{35}$

One of the most dramatic developments of the last half decade has been the rapid extension of employees' rights to fair representation in the negotiation and administration of collective bargaining agreements. An individual employee now may sue his employer for breach of contract, and may join the union or sue it alone if it has treated him arbitrarily, capriciously, or in bad faith. ${ }^{86}$ An employee has no absolute right to have a grievance arbitrated, ${ }^{37}$ however, and he must first pursue any remedies available under the contract before he can file suit. ${ }^{38}$ Important questions in this area await the Court's future attention. Do honesty and conscientiousness excuse any union blunder? Do certain employee rights "vest" so as to be immune from further union-employer bargaining? To what extent may the courts intrude to protect individual rights without impairing effective collective bargaining? This may well be the area in which the Warren Court has left the most unfinished business.

In a celebrated little essay Sir Frederick Pollock remarked, "Caution and valour are both needed for the fruitful constructive interpretation of legal principles." 39 I suspect that others besides Professors Bickel and Wellington have doubts about the Warren Court on the score of caution. My own feeling, however, is that most of its forays are set off by retrenchments. States may not regulate conduct covered by the NLRA; but an exception is carved out for malicious and harmful libel. The courts shall assume responsibility for writing a body of federal contract law; but the day-to-day task is delegated to the arbitrators. Is that not "caution" as well as "valour"? In any event, if I must choose between the two in a field like labor law, the choice is plain.

34. Food Employees Local 590 v. Logan Valley Plaza, Inc., 991 U.S. 308 (1968).

35. IAM v. Street, 367 U.S. 740 (1961); Brotherhood of Ry. \& S.S. Clerks v. Allen, 373 U.S. 113 (1963).

36. Humphrey v. Moore, 375 U.S. 335 (1964); Vaca v. Sipes, 386 U.S. 171 (1967).

37. Vaca v. Sipes, 386 U.S. 171 (1967).

38. Republic Steel Corp. v. Maddox, 379 U.S. 650 (1965).

39. Judicial Caution and Valour, in Jurusprudence IN Action 367, 373 (1953). 